\author{
Gabriel Mircea Talmațchi \\ https://doi.org/10.26485/AAL/2019/65/9
}

\title{
THE MINT OF CALLATIS IN THE HELLENISTIC PERIOD. STAGES AND POSSIBLE MODELS OF PRESENCE, PENETRATION AND POSSIBLE MONETARY CIRCULATION IN THE GRECO-NATIVE ENVIRONMENT
}

\begin{abstract}
The city of Callatis, founded by colonists of Heraclea Pontica, probably in the second half of the 6th century $\mathrm{BC}$, experienced a special period of economic and urban development during the 4th century BC. With its resource-rich agricultural hinterland, the colony sustained a dynamic trade with important commercial centres (Heraclea, Sinope, Thasos, Rhodes etc.). During the second half of the 4th century BC, the local and regional context favoured the opening of a mint that initially struck silver (drachmas, half drachmas and quarter drachmas), then gold (staters) and silver (tetradrachms), as well as bronze coins of various iconographic types. Chronologically, Callatis is the second coin-issuing centre on the west coast of the Dobrudja after Istros. The presence, penetration and possible circulation of monetary issues from Callatis, during the 4th-1st centuries BC, can be traced step by step in different geographic areas, which closely correlate to the directions of trade developed by the colony in different chronological phases. What is noteworthy for the isolated discoveries is, during the fourth century, the widespread distribution of the bronze coins of the city, which are found in overwhelming proportions if we compare them with finds of Greek, Greek-native and native issues (particularly as regards the territory south of the Danube).
\end{abstract}

Keywords: Callatis, coins, monetary circulation, workshop, Dobrudja, Pontus Euxinus, Hellenistic period

ABSTRAKT Kallatis, założone prawdopodobnie w drugiej połowie VI w. p.n.e. przez Herakleję Pontyjską, w IV w. p.n.e. przeżywało okres rozkwitu gospodarczego. Był to również rozwoju urbanistycznego miasta. Kontakty handlowe miasta sięgały, między innymi, Heraklei, Synopy, Tazos i Rodos. Na ten czas przypada rozwój mennictwa Kallatis. Bito początkowo drachmy, hemidrachmy i niższe nominały. Później bito złote statery, srebrne tetradrachmy oraz monety miedziane o rozmaitej ikonografii. Oceniając czas rozpoczęcia produkcji monet w Kallatis zwrócić należy uwagę, że na terenie dzisiejszej Dobrudży wcześniej monety bito jedynie w Histrii. W artykule zaprezentowano dyskusję na temat obiegu monet Kallatis od IV do I w. p.n.e. Zwrócono uwagę na powiązania rozpowszechnienia monet Kallatis z powiązaniami handlowymi miasta.

Słowa kluczowe: Kallatis, monety, obieg monetarny, warsztat, Dobrudża, Morze Czarne, okres hellenistyczny

The town of Callatis was founded on the west coast of the Pontus Euxinus (in Dobrudja) by settlers from Heraclea Pontica, probably in the second half of 6th century BC. ${ }^{1}$ In the 4th century BC it experienced a period of exceptional economic and urban prosperity. Beneficiary of an important adjacent rural area (chora), the colony sustained a dynamic trade as is testified to by the presence of trade amphoras on the local market, which came

Pippidi 1971: 38-39; Avram 1999: 9. from important commercial centres of the time, such as Heraclea, Sinope, Thasos and Rhodes. ${ }^{2}$ The local and regional context favoured the opening of a mint during the second half of the fourth century, which initially struck silver coins (drachmas, half-drachmas and quarter-drachmas), and then gold staters and silver tetradrachms, as well as bronze

2 Buzoianu 1986: 407-415; Avram 1996: 45; Conovici 2005: 109. 
coins of various iconographic types. ${ }^{3}$ From a chronological point of view, Callatis is the second city to have issued coins on the western coast of the Dobrudja, after Histria. ${ }^{4}$ The first coins struck at Callatis have Heracles as their principle device. The choice of this figure was related to the founding myth, being attested to by local inscriptions and other epigraphic sources. ${ }^{5} \mathrm{He}$ is considered to be the founder of the city, and is honoured by a temple in the city dating to the beginning of the 3rd century BC. ${ }^{6}$ On the silver issues his young head appears in profile, covered with the skin of the Nemean lion. The reverse bears his bow, quiver and club (Fig. 1, no. 1-3). The iconography these representations are influenced by mints striking issues of Alexander the Great, especially the founding city, Heraclea Pontica. ${ }^{7}$ From a stylistic point of view, the city has beaten several series of this monetary type. Chronologically, coins were struck irregularly between the years 330-281 BC, although there are indications of the minting of some specimens and in the second half of the 3rd century BC (and perhaps even down to the end of that century). ${ }^{8}$ The first Herakles bronze coins were struck in the last quarter of the 4 th century BC, ${ }^{9}$ bearing on the obverse the young head of the deity, and on the reverse a wheat ear, a club, quiver and bow (Fig. 1, no. 4).

At first the local weight system used by the mint is the standard Aeginetic one (with a local mina of $605 \mathrm{~g}$ ), although it is possible that a Persian reduced weight standard was also used. ${ }^{10}$ The value of the standard unit (mina) gradually declined until the middle of the second half of the 3rd century $\mathrm{BC}$, when a new weight system was adopted, the Attic (with a mina of up to $436 \mathrm{~g}$ ). ${ }^{11}$ The situation remained the same until the end of the pre-Roman period. The state of affairs at Callatis was unexceptional, the same weight standard being adopted by the rest of settlements on the western shore of the Pontus Euxinus.

3 Pick 1898: 86-87; Poenaru Bordea 1997: 61; Preda 1998: 74; Talmațchi 2006a: 39.

4 Talmațchi 2008: 73; Talmațchi 2011: 345; Talmatchi 2016: 428.

5 Covacef 1975: 401; Avram, Poenaru-Bordea 2001: 581 .

6 Avram 1999: 3, with the commentary at p. 95.

7 Preda 1998: 73; Talmațchi 2006b: 106.

8 Talmațchi 2011: 449, 451.

9 Grămăticu, Ioniță 2007a: 25.

10 Iliescu 1976: 94; Preda 1998: 73; Talmațchi 2016: 427, 431 .

11 Ocheșeanu 1975: 154; Marin 2015: 29; Marin 2017: 328
At the end of the 4th century and during the first two decades of the 3rd century BC, the city was occupied by a Macedonian garrison, and was subjected to a prolonged siege by Lysimachus, ruler in Thrace. Shortly after the city seems to recover and resume its important economic and commercial role on the western shore of the Black Sea. At some point in time, after the disappearance of Lysimachus from the historical scene, until the middle of the 3rd century BC, Callatis minted staters and tetradrachms of the 'Alexander' type. Several hypotheses have been advanced as to when these were struck. Most can be accommodated within the period 280-225 BC or even later. Recent studies have revealed a period of intensive minting for a short period of time to support some financial outlay (perhaps the conflict with Byzantium and Ptolemaic Egypt). The mint of Callatis was used by Seleucid rulers down to Antiochus II and by the Macedonian King Antigonus. ${ }^{12}$ After that the minting of the gold coins ceases, at any rate no later than the onset of the 3rd Syrian war (246-241 BC). This last conflagration coincides with the beginning of the striking of Pseudo-Lysimachean coins in the entire western Black Sea (which is closely related to the recruitment of mercenaries for the Mithridatic Wars). ${ }^{13}$ Tetradrachms are very little known and rarely found. This is despite the Callatis mint, when compared to other mints on the western shore of the Pontus Euxinus, was one of the more important ones. But, when set against the background of the magnitude of the historical-monetary phenomena of the period, it can be considered marginal. It is possible that 'Alexander' staters continued to be used during the second half of the 3rd century BC for some donations or loans carried out in the city, which is proved by the epigraphic sources.

For the 3rd-2nd centuries BC there is a lot of evidence pointing to intense political, economic and cultural relations with other centres in the Pontic and Aegean basin both before and after the conflict with Byzantium. ${ }^{14}$ During the same period, there is a lot of evidence for the development of agricultural and manufacturing activities. The prosperity

12 Suggestion made by colleagues Aurel Vîlcu (from the Bucharest Archeology Institute) and Emanuel Petac (from numismatic cabinet of the Romanian Academy), starting from A. Vîlcu, E. Petac, Some remarks on gold staters of Alexander the great type struck at Kallatis (unpublished article).

13 Seyring 1958: 615; Callataÿ 1991: 147, 150; Callataÿ 1995: 45; Vîlcu, Isvoranu, Nicolae 2006: 9; Munteanu 2016: 32.

14 Talmațchi 2007: 41-42; Talmațchi 2016: 428. 


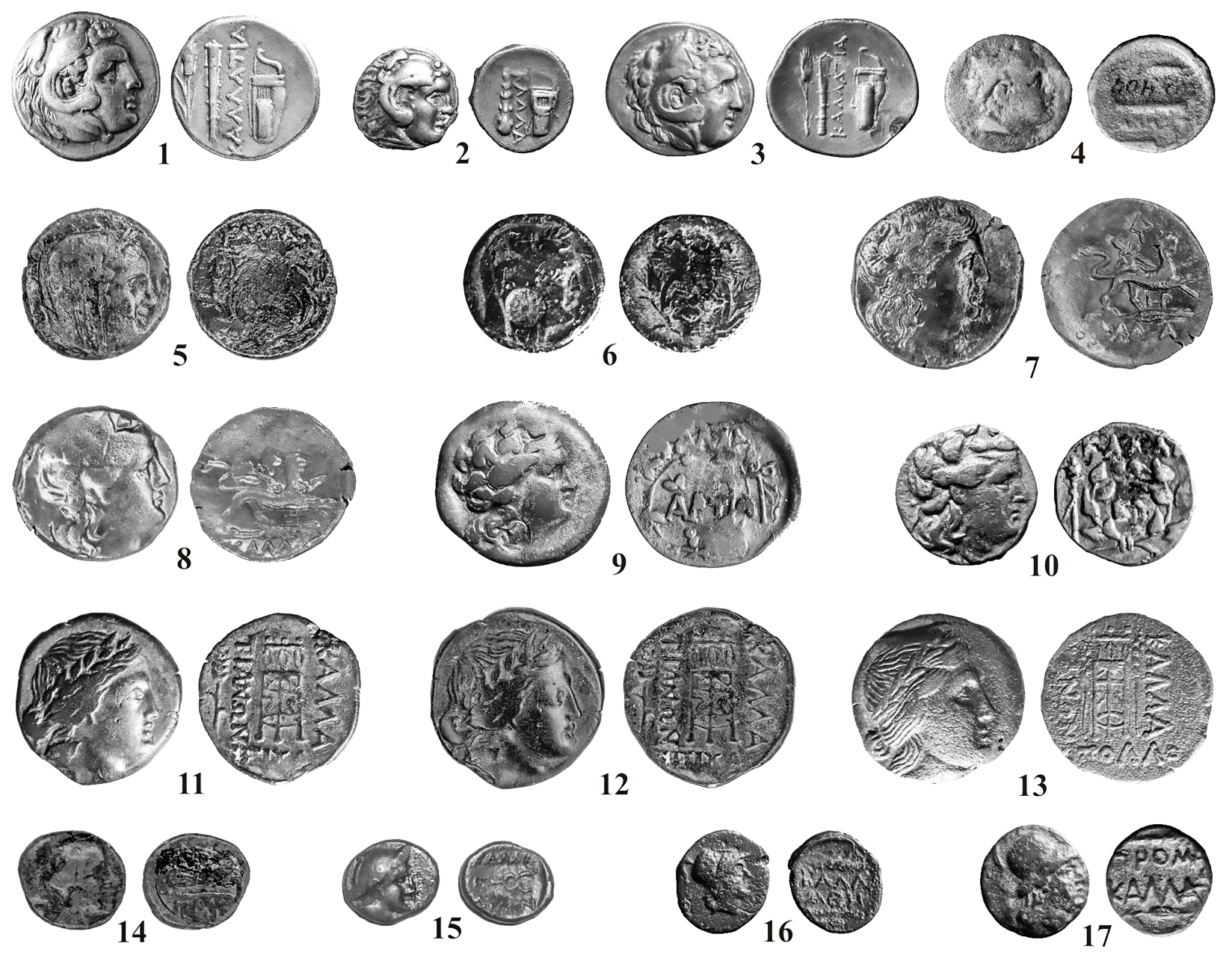

Fig. 1. Monetary types issued at Callatis during the $4^{\text {th }}-1^{\text {st }}$ centuries BC

of the 3rd century BC made it possible for the local mint to issue the majority of the types struck during the autonomous period (activity which was carried on down until the 1 st century $\mathrm{BC}$ ). In bronze these were as follows: Demeter (Fig. 1, no. 5-6), Dionysus/Panther (Fig. 1, no. 7-8), Dionysus/ Wreath (Fig. 1, no. 9-10), Apollo (Fig. 1, no. 11-13), Artemis (Fig. 1, no. 15), Hermes (Fig. 1, no. 15), and Athena (Fig. 1, no. 16-17). The variation of these monetary types, and the shift from silver to bronze was based in part on domestic economic reasons, and in part on propaganda projected towards the external economic and commercial environment. The intensity of this minting depended on the needs of the city and the context of various politico-military events which had an impact on the local area.

In general the coins issued by the city show on the obverse the head of some deity presented in profile..$^{15}$ Their choice from the local pantheon was

15 Talmațchi 2008: 77-78; the multitude of dies used for most of the monetary types issued by the city in the autonomous period points to two possibilities: either a laborious process, which was either a response to the foundation myth, to contemporary artistic and religious influences, to remembered tradition, or could be inspired by statues and other works of art or local temples. The deities represented on these coins are accompanied by specific attributes that emphasize their areas of competence in everyday life. The majority of these divinities are to be found in the numerous inscriptions belonging to the autonomous period of the city, according to the role and the manner in which they were received, reflecting for each of them a special, easy to highlight cult. Thus, Demeter, perhaps the most esteemed divinity in the colony due to her primordial agrarian nature, ${ }^{16}$ Dionysos, who was well-represented and a very popular cult in Callatis, ${ }^{17}$

a massive coin issue at a certain moment, or an extended one over a longer period of time; see Talmațchi 2016: 423-424.

16 Avram 1999: 313, no. 40.

17 Avram 1999: 342-347, no. 48. 
Apollo, widely worshiped, ${ }^{18}$ or Athena as the protector of the city, ${ }^{19}$ etc.

The phases of the circulation and penetration of the coinage of Callatis over different geographical areas during the 4 th to the 1 st centuries $\mathrm{BC}$ is in close correlation to the direction in which the colony traded in different periods. Bronze coins dominate.

Silver coins of the Herakles type appear in isolated finds or treasures inside the city during the 4th and 3rd centuries $\mathrm{BC}$, and in the surrounding territory in the south and southwest of the territory of Pontus. The highest number of coins is naturally recorded at Callatis itself. The pieces which have been found in archaeological contexts are associated with silver coins struck elsewhere: for example at Apollonia Pontica or Mesambria. Moreover some examples appear among the inventories of tumulus graves, which indicates their long-lasting use on the local market and subsequent use as objects endowed with magic-religious purpose. ${ }^{20}$ From the surrounding area, one notes the discovery of objects of this type at Albeşti (in a Hellenistic fortification located about $15 \mathrm{~km}$ away from ancient Callatis, the present-day Mangalia). ${ }^{21}$ They also appear in the southern and western continental basins of Dobrudja (northeast Bulgaria), and in isolated discoveries elsewhere especially in the Karon Limen hoards (in combination with the Demeter and Dionysos/garland bronze coins), and Silistra (in association with a drachma from Histria), seemingly as a result of trade. ${ }^{22}$ Falling outside this area is a drachma of Callatis found in a hoard discovered in south-eastern Bulgaria, in association with post-Alexander III tetradrachms. ${ }^{23}$

Staters and tetradrachms struck in Callatis appear in isolated finds and hoards. As coins with a high purchasing power, they were especially used for payment for military service and less for commercial purposes. Naturally most of them appear in hoards.they were meant mainly for hoarding. Is such hoards staters and tetradrachms of Alexander III type struck in Callatis appear a considerable distance from their place of issue, alongside other "currencies" of the ancient world, which were involved in the Hellenistic trade circuit, for example

18 Pippidi, Berciu 1965: 261; Avram 1999: 93-94.

19 Pippidi 1998: 107, 141; Avram 1999: 399-400, no. 76, with the commentary 94.

20 Preda, Bârlădeanu 1979: 98; Talmațchi 2017a: 287-288, no. 5-10, 295.

21 Talmațchi 2009: 83-103; Talmațchi 2018a: 81-125.

22 Poenaru-Bordea 2004: 61, no. 27, 63, no. 53.

23 Poenaru-Bordea 2004: 61, no. 30. in Asia Minor the hoards from Kirazli, Mektepini and Meydancikkale. ${ }^{24}$ The hidden treasures represented sums for making payments in different forms, including tribute ( $\varphi$ ó $\rho \varsigma$ ) for payment of which the heads of local communities were responsible. This was established by treaties, the size of the contributions being related to the economic power and prestige of the areas controlled..$^{25}$ These payments were made (in precious metal) for military protection of Callatis and other settlements on the west coast of the Pontus Euxinus. To hoards accumulated for this purpose we should add coins paid to individual mercenaries in gold and silver pieces, ${ }^{26}$ and, last but not least, to hoards accumulated as the result of robberies..$^{27}$ Staters struck in Callatis appear in Dobrudja in the hoard discovered at Dăieni (Tulcea County). ${ }^{28}$ Tetradrachms of Callatis appear in three hoards discovered in Silistra and Varna (Bulgaria). ${ }^{29}$ In the first hoard, the pieces are associated with coins struck in Histria and by Seleukos I. The ones in Varna comprise, on the one hand, two pieces of Callatis associated with other issuers such as Alexander III, Lysimachus and Antiochos I. To the north of the Danube we find golden pieces of the Alexander III type with city marks in a barbarian environment, a situation which has been noted in the hoards of Anadol (Republic of Moldova) and Mărășești (Vrancea County). ${ }^{30}$ These last hoards arose due to the contributions of cities in the area to various native political formations. in the native environment, where they have arrived in consignments. A statistical analysis of these finds allows us to conclude that Callatis played an important role in the production of Alexander III staters on the western coast of the Black Sea. ${ }^{31}$

24 Poenaru Bordea 2001b: 568; Poenaru-Bordea 2004: 61, no. 29, no. 32, 62, no. 33; Munteanu 2013: 363.

25 Mitrea 1965: 242-243; Pippidi 1967: 208; Ştefan 1984: 333; Avram 1989: 86; Ruscu 2002: 272-273; Talmatchi 2004: 181.

26 Munteanu 2013: 369-370.

27 Poenaru Bordea 1979: 50; Poenaru Bordea 1999: 159; Ruscu 2002: 301, 305, 307; Munteanu 2005: 253-254; Vîlcu 2010: 207.

28 Poenaru Bordea 2005: 12-13, no. 1-36; Preda, Petac 2006: 30-32, no. 93, 99-103, 107-108, 33-34, no. 110-111, 115-116, 120; Petac 2004-2009: 9-13, no. 1-14.

29 Poenaru-Bordea 2004: 62, no. 39, 63, no. 53.

30 Pridik 1902: 68, no. 188-222, 71, no. 279-414, 76, no. 513-568, 77-78, no. 578-628; Poenaru Bordea 1974: 108-109, no. 64-83; Poenaru Bordea 1979: 42-43, 46; Poenaru Bordea 2004: 59, no. 2, 61, no. 31.

31 Poenaru Bordea 1974: 122; Mihăilescu-Bîrliba 1990: 60; Talmațchi 2004: 182. 
From the 3 rd to the 1 st centuries $\mathrm{BC}$ the bronze coins of Callatis penetrated the local environment in two directions.

The first direction was towards the northeast, and towards the south (between Tomis and Odessos) and southwest of Dobrudja (Fig. 2). ${ }^{32}$ In the context of local economic development, these commercial channels, especially the southwest, must have been heavily used, becoming vital to ensure a prosperous economy and flow of trade.

Bronze coins of the Herakles and Demeter types, which may have been produced since the end of the 4th century or the beginning of the 3rd century $\mathrm{BC}$, are found spreading over an area roughly similar to that of the silver coins of Callatis of the Herakles type. The Herakles type has a more limited presence among coin finds in the Dobrudja, in contrast to inside Callatis itself, and very weakly represented in the regions lying to the south-west and north. The Demeter type has been discovered inside the city, inside the city's chora, or at the border of neighbouring cities, in the southern continental Dobrudja, or occasionally within them (Histria) or in their immediate vicinity. Some discoveries also appear in the northern part of the region, on the Danube, which was a transit zone. As for hoards, coins of this type appear in a discovery made at the Capul Şabla (Balchik, Bulgaria) in association with other coins of Callatis, both silver and bronze issues (Dionysus/wreath). ${ }^{33}$ We can add to this tally the Mangalia hoard discovered in 1962, containing 36 examples of this type, associated with 12 examples of the Dionysos/Panther coins. ${ }^{34}$ This latter type seems to have been issued over a short period, previously only being represented by a single isolated discovery at Adamclisi (Constanta County). ${ }^{35}$ The coins of the Dionysus/wreath of ivy and the Apollo/tripod types seem to be some of the most widespread specimens, which also contributed to the spread of the religious symbols of the city of Callatis in different milieu south of the Danube.

In addition to a significant presence in Callatis, discoveries are concentrated in the southwest, along the Danube in the transit zone, inside settlements (Histria and Tomis) and in their choras. In the centre of Dobrudja a small presence has been identified, with a significant concentration at Pantelimonu

32 Talmațchi 2002-2003: 396; Munteanu 2013: 363.

33 Poenaru-Bordea 2004: 61, nr. 27; Talmațchi 2006a: 89, no. 5.

34 Poenaru-Bordea 2004: 59-60, no. 8; Talmațchi 2006a: 92, no. 15.

35 Talmațchi 2017b: 540-541, no. 18. de Sus (Constanta County). ${ }^{36}$ In the specialized literature dealing with the subject, the Casimcea River valley has been considered as the main route of penetration of the central plateau of the region for Greek merchants advancing from the Black Sea and the current Lake Taşaul in antiquity. ${ }^{37}$ Hoards containing these coin types are numerous, and can divided into the following groups: two in Mangalia, three in south-western Dobrudja, and one on the border between the territories of Callatis and Tomits. The two discovered in Mangalia (in the early 1900s and 1935) show different associations between bronze monetary issues of Callatis. ${ }^{38}$ The first includes eight coins. The second one consists of 16 coins.

The rectangular plan of the city was laid out at some point during the $3 \mathrm{rd}$ and 2 nd centuries BC and was rich in single deposits and hoars of local pieces. In the south-west of the Dobrudjan area we know of two deposits discovered at Adamclisi and one at Şipotele (Constanţa County). ${ }^{39}$ The first deposit consists of four pieces of the Dionysus/ivy crown and Apollo types, and the second of eight coins of the Dionysus/ivy crown, Apollo and probably Demeter types. The Sipotele hoard was composed of five coins of the Dionysus coins/ivy crown type. At Tuzla a small deposit composed of 4 counter-marked coins of Dionysos type has been recorded associated with 6 coins of Tomis of the Apollo and the Great God type. ${ }^{40}$ The vast majority of coins of Callatis present in these hoards (except those of the Apollo type) have been countermarked (once, two or three times), and, as a result, these deposits would have been made during the 1st century 1st century, and especially during the first half of that century. The hoarding of these low-value coins deposits may be due to factors of an economic or non-economic nature. That is, they may represent small payments made for local products in the native environment, or they may have been deposited locally due to external pressure, or even accidental loss. They were, however, relatively small in number.

The penetration of the bronze coins of Callatis into these areas reflects the confidence in the prosperous economy of the city which Callatis enjoyed among the surrounding communities. ${ }^{41}$

36 Talmațchi 2017b: 527-535.

37 Krebs 1998: 100.

38 Poenaru-Bordea 2004: 59-60, no. 8; Talmațchi 2006a: 92 , no. 15

39 Talmațchi 2004-2009: 193-195; Talmațchi 2017b: 541-544, no. $21-27,544-545$, no. $30-34$.

40 Talmațchi 2006a: 94, no. 22.

41 Talmațchi 2017b: 551-552 with all the findings and the respective bibliography. 
The importation of goods and trading contacts had made the native population aware of the Hellenistic lifestyle. Economic and trade relations were on the rise as a result of irreversible changes taking place within local communities due to repeated contact. The import and use of Greek luxury products became essential to different social categories of the local population, not just the elite, and was constantly stimulated and maintained by the Greek coastal settlements.

Callatis had constant commercial relations with foreign ethnic groups, both local (Gaetic) and adjacent (Scythian) populations, which were organized under various political and military structures. In the southern central area of Dobrudja, a series of archaeological discoveries marks the southern Dobrudjan commercial route, which followed the course of the natural valleys and the easiest ways of access ways, linking the settlement at Callatis with various local settlements on the Danube in the vicinity of Callatis..$^{42}$ Bronze coins of Callatis, bearing repeated counter-marks, have been found in much later contexts than their period of issue. In these areas they retain a certain value, alongside other produce coming from Greek workshops, while within the cities they fell completely out of use, and were used as sacred objects, deposited as burial offerings. As an exception to this rule we have the report of a hoard discovered in Preslav (Bulgaria), south of Varna. ${ }^{43}$ It contained a Dionysus/wreath, along with Macedonian bronze coins, and others from Dionysopolis and Mesambria.

Finally, the last bronze coins of the main series from Callatis are those with Athena, Artemis, Hermes and a special type for Demeter. Coins with a representation of Athena on the obverse enjoyed a rich circulation, while those bearing Artemis and Hermes are only discovered sporadically. Concentrations of these coins have been found mainly in the area of the domestic market of Callatis and its rural territory, the fords crossing area to the north of the river, and south-western Dobrudja. The Artemis and Hermes types seem to have come to Dobrudja chaotically, at different points in the north, centre and south, which do not indicate intentional trading, but a random effect of the human element. The only hoard presenting coins from this later group of types of Callatis are those mentioned, from Mangalia, with coins of the Athena type found in association with Apollo

42 Conovici, Irimia 1991: 140-141.

43 Poenaru Bordea 2004: 62-63, no. 46; Talmațchi 2006a: 147 , no. 11 . or Dionysus/ivy crown types. ${ }^{44}$ The discovery of these coin types of Callatis in the local environment probably indicates the beginning of the penetration of this area by local merchants. These same trends become evident in Dobrudja at a later period, from the second part of the 2 nd century to the beginning of the 1 st century BC.

Several coins of the Demeter type bearing the name APISTQN on the reverse are of particular importance. This magistrate in charge of issuing coins could be a member of an important family from Callatis, which is known from epigraphic evidence to have been a benefactor of the city, along with his son, Ariston, son of Ariston. ${ }^{45}$ On the obverse of coins of this type the veiled head of the goddess is represented as wearing a wreath made from ears of wheat, facing right, in a circle of beads, bearing on the reverse two ears of wheat. According to the epigraphic sources and the monetary legend, these coins could be dated before the end of the 1 st century $\mathrm{BC}$, probably in the last three decades in which the city continued to enjoy autonomy. ${ }^{46}$

The second main direction of penetration of the coins of Callatis lay in the territories north of the Danube, Wallachia and southern Moldavia. These areas had been under the economic and commercial influence of Histria until the 3rd century BC, but its general situation did not allow it to retain control. ${ }^{47}$ A certain density of discoveries near the northern bank of the Danube could be related to some commercial warehouses used by merchants to further spread products from Callatis to fortified settlements in the receiving areas. ${ }^{48}$

An analysis of the finds allows us to confirm the presence of almost all monetary types of the city in this area, even if it is immediately evident to which precise issue these pieces belong. We can enumerate the Heracles type, the Demeter type, and others not specified. Isolated discoveries have been made in several local centres located on or near the course of tributaries of the Danube, deep inside the indigenous communities.

The way in which these coins could have been deposited is most probably to be explained in the chance losses of merchants or Greek citizens

44 Poenaru-Bordea 2004: 59-60, no. 8; Talmațchi 2006a: 92, no. 15.

45 Avram 1999b: 50-54, nos 40-42, 44-45; the same opinion is shared by Grămăticu, Ioniţă 2006-2007: 6162; Grămăticu, Ioniţă 2007b: 34-35.

46 Grămăticu, Ioniţă 2006-2007: 70; Grămăticu, Ioniță 2007b: 42.

47 Talmaţchi 2002-2003: 396.

48 Talmațchi 2004: 176, 178-179. 


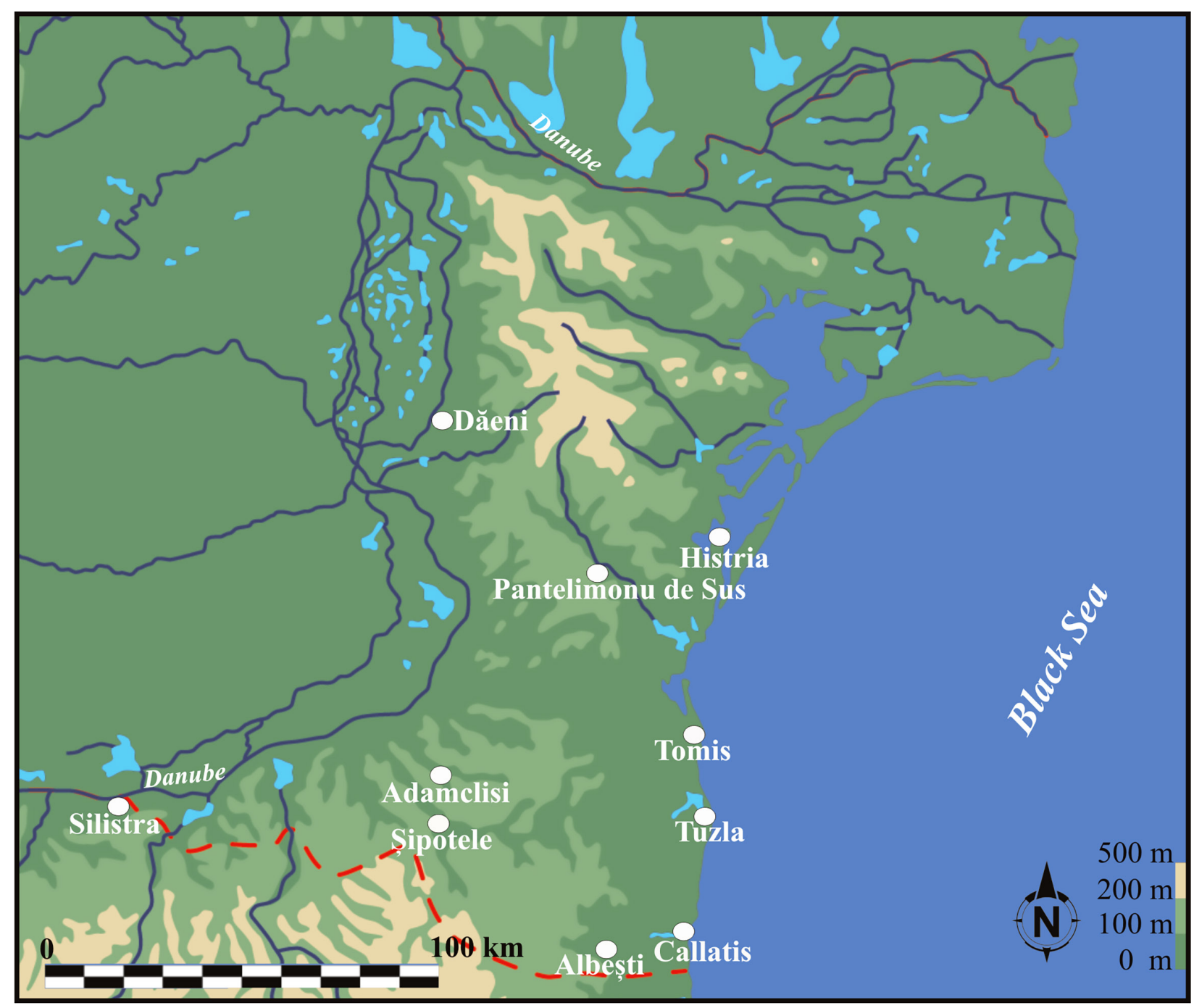

Fig. 2: Map of Dobrudja with the most important localities present in the article with isolated Callatian monetary discoveries and treasures

passing through the area. We can almost exclude the possibility of the coins being used in local payments, although not completely. So we are probably not dealing with the existence of any kind of monetary circulation to the north of the Danube. The only possible option for bronze coins is for them to have penetrated into the area in such a fashion. ${ }^{49}$ The only hoard consisting of bronze coins known in this area, comes from Poiana (Nicorești, Galati County)..$^{50}$ It was discovered in a Gaeto-Dacian settlement, in an archaeological context broadly dated to between the beginning of the 3 rd century and the first half of the 1 st century BC. It consists of 32 bronze coins of the Apollo/tripod type.

49 Mihăilescu-Bîrliba 1990: 50; Talmațchi 2004: 176-177; Talmaţchi 2006a: 44; Talmaţchi 2011: 452-453.

50 Teodor, Nicu, Țau 1987: 133-138; Teodor, Mihăilescu-Bîrliba: 1993, 128, nr. 5-36; Marin 2018: 87-117.
In much more remote areas, we come across isolated discoveries in the northern Black Sea region, such as the Crimean Peninsula (from Kherson); ${ }^{51}$ or those in the southern central part of Bulgaria today, from Aytoska-Bania, Momino, Smoljan, etc. ${ }^{52}$

The political and military events of the end of the 1st millennium $\mathrm{BC}$ necessitated, on the one hand, the city being in a constant state of readiness, and on the other hand engaging in negotiations or in military conflicts caused by overwhelming aggression, be it from the Kingdom of Pontus, Republican Rome and the Dacian kingdom of Burebista. ${ }^{53}$ The situation of settlements on the Western Black Sea coast was often precarious, with the political

51 Poenaru-Bordea 2004: 60, no. 10.

52 Talmațchi 2006a: 148, no. 2; Poenaru-Bordea 2004: 60 , no. 18,62 , no. 34 , no. 42 , 63 , no. 54 .

53 Crișan 1977: 255; Suceveanu 1977: 17; Talmațchi 2016: 432. 
and military events experienced frequently creating a constant turbulent period. This created a set of circumstances not favourable for an expansion of economic life, and, last but not least, creating a state of internal tension. Harvests will have been frequently subjected to theft and loss, which will have had direct consequences on food resources, and the colder financial prosperity of the colony, its weaknesses becoming increasingly evident. The frequent interruptions in minting during the 1 st century $\mathrm{BC}$, reflects this economic instability and lack of local resources.

The latest bronze coins issued by the local mint date to the end of the third quarter of the 1 st century BC. The iconography of these issues seem to be oriented towards the protective divinities of agriculture as benefactors, or characters with great local authority. This is because cereal products came to play a central role in the community. Their presence could provide internal peace and survival in troubled times. The same situation seems to be reflected generally in the monumental iconography of the western Black Sea coast, as can be seen, for example, at Histria and Dionysopolis..$^{54}$ During this period Callatis, and all the other Western Pontic cites became subjects of the Roman Empire, entering a new period of its history, which lie outside the realm of this article. ${ }^{55}$

\section{Literature}

Avram A. 1989. Pentru o fenomenologie a raporturilor dintre geţi și greci, Symposia Thracologica 7, București, 70-93.

Avram A. 1996. Histria. Les résultats des fouilles. VIII, Les timbres amphoriques, 1. Thasos, Bucarest-Paris.

Avram A. 1999. Inscriptions grecques et latines de Scythie Mineure, volume III. Callatis et son territoire, Bucarest-Paris.

Avram A. and Poenaru-Bordea Gh. 2001. Coloniile greceşti din Dobrogea. In M. PetrescuDîmboviţa, Al. Vulpe (eds.), Istoria Românilor, vol. I., Moştenirea Timpurilor Indepărtate, București, 533-634.

Buzoianu L. 1986. Les premières importations d'amphores timbrés dans les cités grecques de Tomis et de Callatis, BCH, supplément XIII, 261.

${ }^{54}$ Canarache 1957: 61-78; Talmațchi 2018b: 258,

55 Pippidi 1976: 452. recherches sur les amphores grecques. Paris, 407-416.

Callataÿ F. 1991. L'histoire des guerres mithridatiques vue par les monnaies, Louvain-la-Neuve.

Callataÿ F. 1995. Les derniers statères posthumes de Lysimaque émis à Istros, Tomis et Callatis. In S. Torbatov, V. Yotov (ed.), Numismatic and Sphragistic Contributions to Ancient and Medieval History of Dobrudja. International Symposium, Dobrich 1993, Dobrudža 12, Dobrič, 39-50.

Canarache V. 1957. Monetele autonome inedite din Dionysopolis și cronologia lor relative, $\mathrm{SCN} 1$, 61-78.

Conovici N. 2005. The dynamics of trade in transport amphoras from Sinope, Thasos and Rhodos on the Western Black Sea Coast: a comparative approach. In Vl.F. Stolba, L. Hannestad (eds.), Chronologies of the Black Sea area in the period c. 400-100 BC, Black Sea Studies 3, Danish National Research Foundation`s Centre for Black Sea Studies, Aarhus, 97-117.

Conovici N. and Irimia M. 1991. Timbres amphoriques et autres inscriptions céramiques découverts à Satu Nou (comm. d' Oltina, dép. de Constantza), Dacia N.S. 35, 139-175.

Covacef Z. 1975. Contribuţii privind cultul lui Hercule in Scythia Minor, Pontica 8, 399-428.

Crișan I. H. 1977. Burebista şi epoca sa, București.

Grămăticu S. and Ioniță V. 2006-2007. Monede de bronz inedite de la Callatis din secolele I a.Chr.-I p.Chr., Cercetări Numismatice 12-13, București, 59-73.

Grămăticu S. and Ioniță V. 2007a. Primele emisiuni monetare de bronz ale atelierului din Callatis. In E. Nicolae (ed.), Simpozion de Numismatică organizat cu ocazia comemorării Sfântului Ştefan cel Mare, domn al Moldovei (15042004), Chişinău, 29 septembrie-2 octombrie 2004, Comunicări, Studii şi Note, Bucureşti, 9-28.

Grămăticu S. and Ioniţă V. 2007b. Monniaes de bronze inédites de Callatis du Ier siècle av. J.-C. et du $I^{e r}$ siècle ap. J.-C., NC 167, 33-45.

Iliescu O. 1976. Le système monétaire et pondéral à Histria, Callatis et Tomis aux $V^{e}-I I^{e}$ siècles $a v$. notre ère. In Actes du 8ème Congrès International de Numismatique, New YorkWashington, septembre 1973, Paris-Bâle, 85-98.

Krebs S. A. 1998. Intensive survey in the vicinity of late roman Ulmetum, SCIVA 49/1, 97-125.

Marin S. 2015: On the metrology of the city of Istros in the autonomous period, Dacia NS 59, 21-47. 
Marin S. 2017. Hellenistic lead weights, Revista de Cercetări Arheologice și Numismatice 3, București, 323-335.

Marin S. 2018, O nouă prezentare a tezaurului de monede callatiene de la Poiana, jud. Galați. In L. Munteanu, C.D. Nicola, G.M. Talmațchi, Studia numismatica et Archaeologica. In honorem magistri Virgilii Mihăilescu-Bîrliba oblate, Bibliotheca Memoriae Antiquitatis XXXIX, București/Piatra Neamţ, 87-117.

Mihăilescu-Bîrliba V. 1990. Dacia răsăriteană în secolele VI-I î.e.n. Economie şi monedă, Iași.

Mitrea B. 1965. Monede antice și feudale descoperite la Zimnicea, SCIV 16/2, 239-260.

Munteanu L. 2005. Quelques considérations concernant les découvertes des monnaies d'or de type Lysimaque dans la Dacie intracarpatique.In V.Cojocaru(ed.), Ethnic Contacts and Cultural Exchanges North and West of the Black Sea (from the Greek Colonization to the Ottoman Conquest), Iaşi, 237-254.

Munteanu L. 2013. Legăturile orașelor grecești vest-pontice cu populațiile barbare în epoca elenistică. Evidența numismatică. In Fl. Panaint Bîrzescu, I. Bîrzescu, Fl. Matei-Popescu, A. Robu (eds.), Poleis in the Black Sea area: Inter-pontic relations and local productions, București, 358-392.

Munteanu L. 2016. The coins of the western pontic greek cities and the "Barbarian" population in the Hellenistic period, Acta Musei Tutovensis $\mathrm{XII}_{2}$, In honorem Ion Ioniță octogenarii, Bârlad, 27-39.

Ocheșeanu R. 1975. Ponduri inedite din Callatis şi Tomis, Studii și Cercetări Numismatice 6, București, 153-155.

Petac E. 2004-2009. Noi date privind tezaurele de monede de aur din perioada elenistică descoperite în Dobrogea: o nouă cronologie a tezaurului de la Dăeni, jud. Tulcea, BSNR 98-103, 9-20.

Pick B. 1898. Die Antiken Münzen NordGriechenlands. Band I. Dacien und Moesien, Berlin.

Pippidi D.M. 1967. Contribuţii la istoria veche a României², București.

Pippidi D.M. 1971. I greci nel basso Danubio dall 'età arcaica alla conquista romana, Milano.

Pippidi D.M. 1976. Gètes, Grecs et Romains en Scythie Mineure : coexistence politique et interférences culturelles. In D. M. Pippidi (ed.), Travaux du VI Congres international d'études classiques. Assimilation et résistance à la culture gréco-romaine dans le monde ancien, Madrid, Septembre, 1974, Bucharest-Paris, 445-453.
Pippidi D.M. 1998. Studii de istorie a religiilor antice. Texte şi interpretări, Bucharest.

Pippidi D.M. and Berciu D. 1965. Din istoria Dobrogei. Geţi şi greci la Dunărea de Jos din cele mai vechi timpuri pînă la cucerirea romană, Bucharest.

Poenaru Bordea Gh. 1974. Le trésor de Mărăşseşti. Les statères en or des cités du Pont Gauche et le problème des relations avec le monde grec et les populations locales aux $\mathrm{VI}^{\mathrm{e}} \mathrm{I}^{\mathrm{er}}$ siècles av.n.è., Dacia 18, 103-125.

Poenaru Bordea Gh. 1979. Les statères ouestpontiques de type Alexandre le Grand et Lysimaque, RBN 125, 37-51.

Poenaru Bordea Gh. 1997. Emisiunile monetare ale atelierelor greceşti de pe litoralul românesc al Mării Negre (sec. VI î.Hr.-III d.Hr.). Un stadiu al problemei. In G.G. Potra (ed.), 130 de ani de la crearea sistemului monetar românesc modern, București, 56-70.

Poenaru Bordea Gh. 1999. A propos du Pont Occidental et du Bas-Danube à l'époque de Mithridate VI Eupator, RBN 145, 155-164.

Poenaru Bordea Gh. 2004. La diffusion des monnaies d'Istros, Callatis et Tomi du VIe au $I^{e r}$ siècle av. J.-C. dans leurs territoires, zones d'influences et ailleurs. In V. Marrazza et alii (eds.), Presenza e funzioni della moneta nelle chorai delle colonie greche dall'Iberia al Mar Nero, Atti del XII Convegno organizzato dall'Università „Federico II" e dal Centro Internazionale di Studi Numismatici, Napoli, 16-17 giugno 2000, Roma, 27-70.

Poenaru Bordea Gh. 2005. Tezaurul de la Dăeni, jud. Tulcea. Catalogul monedelor din colecţia Muzeului Naţional de Antichităţi. In E. Nicolae (ed.), Simpozion de Numismatică, dedicat Centenarului Societăţii Numismatice Române (1903-2003), Chişinău, 26-28 noiembrie 2003, Comunicări, studii şi note, Bucureşti, 11-22.

Preda C. 1998. Istoria monedei în Dacia preromană, București.

Preda C., Bârlădeanu E. 1979. Săpăturile arheologice de salvare din zona șantierului naval de la Mangalia (1974), Pontica 12, 97-107.

Preda C. and Petac E. 2006. Les monnaies d'or de la Bibliothèque de l'Académie Roumaine. I. Monnaies grecques et romaines, Wetteren.

Pridik E.M. 1902. Anadol'skii klad zolotykh staterov 1895 goda, Izvestij a Imperatorskoj Archeologičeskoj Kommissii 3, St.-Petersburg, 58-92, pl. 8-13.

Ruscu L. 2002. Relaţiile externe ale oraşelor greceşti de pe litoralul românesc al Mării Negre, Cluj-Napoca. 
Seyring H. 1958. Parion au $3^{e}$ siècle avant notre ère. In Harald Ingholt (ed.), Centenial Publication of The American Numismatic Society, New York, 603-625.

Suceveanu A. 1977. Viaţa economică în Dobrogea Romană-secolele I-III e.n., Bucharest.

Ștefan A. 1984. Relations étrangères des cités du Pont Gauche à l'époque hellénistique. In J. Harmatta (ed.), Actes du VII Congrès de la Fédération Internationale des Associations d'Études Classiques, I, Budapest, 329-338.

Talmaţchi G. 2002-2003. Scurtă privire asupra ariei de difuzare a monedelor autonome emise de Callatis și Tomis, Pontica 35-36, 395-408.

Talmaţchi G. 2004. Aspecte privind circulaţia monedelor în spaţiul extracarpatic dintre Dunăre și Nistru emise de coloniile grecești vest-dobrogene (sec. V-I a.Chr.). In I. Cândea et alii (eds.), Prinos lui Petre Diaconu la 80 de ani, Brăila, 175-182.

Talmațchi G. 2004-2009. Un lot de monede callatiene autonome descoperite la Adamclisi, jud. Constanța, BSNR 98-103, 193-195.

Talmaţchi G. 2006a. Les monnaies autonomes d'Istros, Callatis et Tomis. Circulation et contexte, Wetteren.

Talmațchi G. 2006b. Aspecte iconografice privitoare la monedele emise de către coloniile vest-pontice dobrogene Callatis şi Tomis în epocă autonomă. In L. Mihăilescu-Bîrliba, O. Bounegru (eds.), Studia Historiae et Religionis Daco-Romanae, In honorem Silvii Sanie, Bucureşti, 105-112.

Talmațchi G. 2007. The Mint's Issues from the Black Sea Coast and other Areas of Dobrudja. The Pre-Roman and Early Roman Periods (6 $6^{\text {th }}$ century B.C.- $1^{\text {st }}$ century A. D.), Cluj-Napoca.

Talmațchi G. 2008. Noi date privind viaţa religioasă la Histria, Callatis şi Tomis din perspectiva iconografiei monetăriilor locale (secolele V-I a.Chr.), Revista Bistriţei 22, 73-83.

Talmațchi G. 2009. Descoperiri monetare in zona fortificației de la Albești com. Albești, jud. Constanța), BSNR 98-103, 83-103.
Talmațchi G. 2011. Monetăriile orașelor vest-pontice Histria, Callatis și Tomis în epoca autonomă. Iconografie, legendă, metrologie, cronologie și contramarcare, Cluj-Napoca.

Talmațchi G. 2016. The Coinage of Callatis in the Hellenistic Period revisited. In A. Robu, I. Bîrzescu (eds.), Mégarika. Nouvelles recherches sur Mégare, les cités de la Propontide et du Pont-Euxin, Archéologie, épigraphie, histoire, Actes du colloque de Mangalia (8-12 juillet 2012), Paris, 439-450.

Talmațchi G. 2017a. Pentru o Restitutio in Integrum-despre câteva descoperiri elenistice din jurul jumătății secolului $X X$, Revista de Cercetări Arheologice și Numismatice 3, 275-305.

Talmațchi G. 2017b. Despre comunitățile greco-autohtone din zona centrală și sud-vestică a Dobrogei în perioada elenistică. Evidențele arheologice și monetare, Pontica $50,525-562$.

Talmațchi G. 2018a. Despre unele descoperiri monetare din imprejurimile fortificației elenistice de la Albești (com. Albești, jud. Constanța), Istros 24, Brăila, 81-125.

Talmațchi G. 2018b. Considerații privind activitatea monetăriei histriene în perioada elenistică din perspectiva câtorva serii rare de bronz din tipurile Apollo și Demetra, Revista de Cercetări Arheologice și Numismatice 4, 254-266.

Teodor S. and Mihăilescu-Bîrliba V. 1993. Descoperiri monetare din aşezarea geto-dacică de la Poiana-Tecuci, ArhMold 16, 121130.

Teodor S. and Nicu M. and Ţau S. 1987. Tezaurul de monede callatiene descoperit la Poiana, judeţul Galaţi, Thraco-Dacica 8, 133-138.

Vîlcu A. 2010. Sur les statères en or de type Koson. In R. Băjenaru et alii (eds.), Recent Studies on Past and Present. I. Human Heritage and Community: Archaeology in the Carpathians and Lower Danube Area from Prehistory to the Early Medieval Age, Transylvanian Review, 19, Suppl. 5.1, Cluj-Napoca, 199-212.

Vîlcu A. and Isvoranu T. and Nicolae E. 2006. Les monnaies d'or de l'Institut d'Archéologie de Bucarest, Wetteren.

\author{
Gabriel Mircea Talmațchi \\ ORCID 0000-0001-5854-3663 \\ The National Museum \\ of History and Archaeology \\ Constanța, Romania \\ gtalmatchi@yahoo.com
}

